\title{
KEMAMPUAN BERPIKIR KRITIS DAN METAKOGNISI SISWA DALAM MENYELESAIKAN MASALAH MATEMATIKA MELALUI PENDEKATAN PROBLEM SOLVING
}

\author{
M. Ikhsan ${ }^{1)}$, Said Munzir ${ }^{2)}$, Lia Fitria ${ }^{2)}$ \\ 1),2),3) Program Studi Magister Pendidikan Matematika Universitas Syiah Kuala \\ Email: ikhsan@unsyiah.ac.id ${ }^{\text {1) }}$, smunzir2001@yahoo.com ${ }^{2)}$, lia.fitria88@gmail.com ${ }^{3)}$,
}

\begin{abstract}
The aims of this study are to determine the improvement of critical thinking skills mathematical and metacognition of students who are taught with problem solving approach and the correlation between mathematical critical thinking and metacognition of students. This research is an experimental research with pretest-posttest control group design. The sample this research is the students of class VIII_2 and VIII_3 in SMP Negeri 1 Banda Aceh. Collecting data technique are test and nontest. Data were analyzed using t-test and correlation test. The result of the research shows 1) the critical thinking ability of the students who get the learning through problem solving approach is better than the students who get the conventional learning, 2) Metacognition of students who get the learning by using problem solving approach is better than the students who get the conventional learning, 3) a positive and significant relationship between students' metacognition and critical thinking skills.
\end{abstract}

Keywords: mathematical critical thinking skills, metacognition, problem solving approach.

\section{PENDAHULUAN}

Perkembangan ilmu pengetahuan dan teknologi akan terus berkembang mengikuti perubahan zaman. Salah satu bidang ilmu yang berperan penting dan menjadi dasar dalam mempelajari ilmuilmu lain serta menjadi alat pikir manusia sebagai landasan dari perkembangan teknologi modern adalah Matematika (Prihandoko, 2006). Ilmu Matematika tidak hanya terbatas pada pemecahan masalah dengan menggunakan formula-formula yang kompleks, tetapi juga merupakan batu pijakan mengenai bagaimana cara seseorang berpikir dan menerapkan hal yang dipelajari dalam kehidupan nyata. Wale (2006) mendefinisikan matematika sebagai suatu ilmu yang mempunyai keteraturan dalam segi pola dan memiliki urutan secara logis.
Matematika dapat menjadi bekal bagi siswa untuk meningkatkan kemampuan memecahkan permasalahan dalam kehidupan sehari-hari, berpikir logis dan analitis sistematis. Keberadaan matematika membantu siswa dalam memperoleh, memilih dan mengelola informasi serta menguasai berbagai permasalahan dan membentuk pola berpikir.

Berpikir menurut Suharnan (2005) memiliki arti sebagai suatu proses yang menghasilkan gambaran mental yang baru dengan mentransfer pengetahuan maupun informasi yang melibatkan interaksi kompleks seperti penilaian, penalaran dan pemecahan masalah. Melalui berpikir manusia dapat mengenali masalah, memahami dan memecahkannya. Hasil dari berpikir dapat berupa ide-ide, 
pengetahuan, alasan-alasan dan untuk proses berpikir yang lebih tinggi hasilnya dapat berupa keputusan. Khodijah (2006) mendeskripsikan berpikir adalah sebuah gambaran atau representasi sebuah simbol dari beberapa peristiwa. Selanjutnya dalam proses berpikir terdapat langkahlangkah dimulai dari pembentukan pengertian, pembentukan pendapat higga akhirnya menarik kesimpulan atau pembentukan keputusan (Suryabrata, 2004).

Berpikir kritis merupakan suatu proses yang berpusat atau bermuara pada pembuatan dan penarikan kesimpulan atau keputusan yang logis tentang tindakan apa yang harus dilakukan dan apa yang harus dipercaya atau diyakini Ennis (Fisher, 2001). Kemampuan berpikir kritis diperlukan dalam menyelesaikan masalah-masalah matematika, karena dalam berpikir kritis, siswa melakukan selangkah demi selangkah, dan dilakukan dengan menghubungkan semua informasi yang ada (Ismaimuza, 2013; Friedrichsen, 2001). Hal ini mengindikasikan bahwa karakteristik berpikir kritis berhubungan erat dengan kesadaran terhadap kemampuan diri sendiri untuk mengembangkan berbagai cara yang mungkin ditempuh dalam menyelesaikan suatu masalah.

Kemampuan dan pengetahuan seseorang menegenai proses berpikir dan hasil berpikirnya atau apapun yang berkaitan dengan proses dan hasil berpikir tersebut mengacu pada pengertian metakognisi menurut Flavell (Iway, 2011). Metakognisi (metacognition) merupakan suatu istilah yang diperkenalkan oleh Flavell pertama kali pada tahun 1976. Menurut Flavell metakognisi terdiri dari pengetahuan metakognisi dan pengalaman atau regulasi metakognisi. Pengetahuan metakognisi merujuk pada diperolehnya pengetahuan tentang proses-proses kognitif, pengetahuan yang dapat dipakai untuk mengontrol proses kognitif. Sedangkan pengalaman metakognisi adalah proses-proses yang dapat diterapkan untuk mengontrol aktivitas-aktivitas kognitif dan mencapai tujuan-tujuan kognitif (Livingston, 2003). Terlaksananya proses metakognisi dalam memecahkan masalah memungkinkan terbangunnya pemahaman yang kuat dan menyeluruh terhadap masalah disertai alasan yang logis Selain berhubungan erat dengan kemampuan berpikir kritis, metakognisi juga merupakan salah satu kunci kesuksesan dalam menyelesaikan suatu masalah. Pada kaitannya metakognisi dengan penyelesaian masalah matematika, beberapa peneliti (Gama, 2004; Panoura, 2006; Yong \& Kiong, 2006; Yildirim, S \& Zehra, 2013) mengemukakan bahwa keberhasilan seseorang dalam menyelesaikan masalah turut dipengaruhi oleh metakognisinya.

Masalah dalam matematika didefinisikan sebagai suatu persoalan yang tidak mempunyai prosedur rutin dalam pengerjaannya (Ruseffendi, 2005). Masalah dapat disajikan dalam bentuk soal non-rutin, soal cerita, penggambaran fenomena atau kejadian, ilustrasi gambar, atau teka-teki. Masalah tersebut kemudian disebut masalah matematika karena mengandung konsep matematika. Masalah menurut Hudoyo (2003) dapat berupa masalah translasi, masalah aplikasi, masalah proses, dan masalah teka-teki. Hamzah (2003) menyatakan bahwa suatu situasi tertentu dapat merupakan masalah bagi orang tertentu, tetapi belum tentu merupakan masalah bagi orang lain. Dengan kata lain, suatu situasi mungkin merupakan masalah bagi seseorang pada waktu tertentu, akan tetapi belum tentu merupakan masalah baginya pada saat 
yang berbeda. Seorang siswa akan menganggap suatu pertanyaan menjadi masalah apabila siswa mengalami kesulitan dalam mencari solusi dari soal atau pertanyaan dengan menggunakan pengetahuan yang dimilikinya. Siswa akan mampu menyelesaikan suatu masalah, jika siswa tersebut benar-benar memahami prinsip-prinsip yang telah dipelajari sebelumnya.

Masih rendahnya kemampuan siswa dalam menyelesaikan masalah pada pelajaran matematika dibuktikan dengan survey yang dilakukan oleh Trends in Internasional Mathematics and Science Study (TIMSS), Indonesia berada diurutan ke-45 dari 50 negara peserta denga skor rata-rata 397, sedangkan skor rata-rata internasional 500. Kondisi yang tidak jauh berbeda juga terlihat dari hasil study yang dilakukan PISA 2015 lebih memprihatinkan, berturut-turut rata-rata skor pencapaian siswa-siswi Indonesia untuk Sains, Membaca dan Matematika berada di peringkat 62,61, dan 63 dari 69 negara yang dievaluasi. Peringkatdan rata-rata skor yang diperoleh Indonesia tersebut tidak jauh selisihnya dengan hasil tes dan survey PISA pada tahun 2012. Pada studi TIMSS terungkap bahwa siswa Indonesia lemah dalam menyelesaikan soal-soal non-rutin yang berkaitan dengan penalaran yang menggunakan data tabel/grafik. Hal tersebut terlihat bahwa hanya 4 persen yang benar.

Nugraha (2011) mengungkapkan bahwa masih terdapat banyak kendala dan permasalahan dalam mengatasi kesulitan siswa untuk mengembangkan proses berpikir, terutama berkaitan dengan berpikir kritis dalam menyelesaikan masalah dalam matematika. Siswa terbiasa menyelesaikan soal-soal tersebut secara singkat dan langsung pada penyelesaiannya. Selain itu, siswa mengalami kesulitan dalam menyelesaikan soal-soal berbentuk soal cerita (soal aplikasi). Kesulitan tersebut terjadi ketika membaca makna yang tersirat dan kesulitan mengkonversi kedalam pernyataan matematika. Siswa lebih mudah memahami atau menyelesaikan soal-soal berbentuk konsep atau pengertian dengan hanya menghafal saja. Hal ini disebabkan karena kemampuan berpikir siswa belum sistematis dalam menyusun langkah-langkah penyelesaian.

Berdasarkan hasil observasi awal dan wawancara dengan guru bidang studi matematika di SMP Negeri 1 Banda Aceh tentang proses siswa dalam menyelesaikan masalah-masalah matematika, kebanyakan siswa lebih mudah dalam menyelesaikan soal-soal yang berbentuk konsep dan rumus. Namun ketika dihadapkan pada soalsoal yang non-rutin dan soal berbentuk aplikasi, siswa merasa bingung dalam mengkorversi ke dalam model matematika. Hal ini terjadi karena siswa masih sangat sulit untuk mengontrol kemampuan berpikirnya dalam menyelesaikan soal yang diberikan, sehingga dari beberapa siswa mengetahui jawabannya tetapi tidak mengetahui bagaiman menyusun penyelesaian dari permasalahan tersebut. Demikian juga berdasarkan hasil wawancara dengan beberapa siswa, permasalahan tidak menyadari kemampuan berpikirnya terjadi karena siswa terbiasa menyelesaikan soal matematika dengan rumus atau dengan cara cepat seperti yang diajarkan di tempat-tempat siswa les di luar sekolah, sehingga ketika siswa ditanya bagaimana memperoleh penyelesaian masalah tersebut, maka siswa kebingungan karena tidah memahami konsep dari masalah yang akan diselesaikan. 
Berdasarkan permasalahan di atas, maka salah satu alternatif metode pembelajaran yang memungkinkan untuk membantu siswa dalam menyelesaikan masalah matematika sehingga dapat mengembangkan berpikir kritis dan metakognisi siswa dalam pembelajaran matematika adalah Pendekatan Problem Solving. Setiawan (2008) menjelaskan tentang pendekatan problem solving adalah suatu cara menyajikan pelajaran dengan mendorong pesrta didik untuk mencari atau memecahkan suatu masalah/persoalandalam rangka pencapaian tujuan pengajaran. Pendekatan problem solving merupakan suatu pendekatan pembelajaran yang memungkinkan siwa memperoleh pengalaman menggunakan pengetahuan serta keterampilan yang sudah dimiliki untuk diterapkan pada pemecahan masalah yang tidak rutin.

Ada banyak langkah pendekatan dari seseorang dalam memecahkan masalah, bergantung tingkat kesulitan masalah, namun urutannya adalah langkah-langkah kreatif yang biasa dilakukan dalam problem solving (Peng, 2004). Djamara (2006) menjelaskan bahwa pendekatan problem solving bukan hanya sekedar metode mengajar tetapi juga merupakan suatu metode berpikir, sebab dalam problem solving dapat menggunakan metode lain yang dimulai dari mencari data sampai kepada menarik kesimpulan. Tahapan pembelajaran melalui pendekatan problem solving atau pemecahan masalah dapat dilakukan melalui beberapa langkah.

Problem solving menurut Dewey dalam bukunya Gulo (2002) dapat dilakukan melalui enam tahap. Sedangkan dalam penelitian ini menggunakan tahapan pendekatan problem solving menurut Polya (Gulo, 2002) yaitu 1) memahami masalah, 2)merencanakan penyelesaian, 3) menyelesaikan masalah sesuai rencana, 4) memeriksa kembali prosedur dan hasil penyelesaian. Berdasarkan latar belakang masalah diatas, maka penelitian ini dilakukan untuk menyelidiki apakah peningkatan kemampuan berpikir kritis dan metakognisi siswa yang diajarkan dengan pendekatan problem solving serta korelasi antara kemampuan berpikir kritis matematis dan metakognisi siswa.

\section{METODE PENELITIAN}

Penelitian ini merupakan penelitian eksperimen dengan desain pretest-posttest control group design yaitu dengan memberi dua perlakuan berbeda terhadap dua kelompok siswa. Kelompok pertama diberikan pembelajaran melalui pendekatan problem solving sebagai kelas eksperimen, sedangkan kelompok kedua mendapat pembelajaran dengan pendekatan konvensional sebagai kelas kontrol. Populasi dalam penelitian ini adalah seluruh siswa kelas VIII SMP Negeri 1 Banda Aceh. Adapun teknik pengambilan sampel pada penelitian ini adalah simple random sampling, yaitu setiap unsur dari keseluruhan populasi mempunyai kesempatan yang sama untuk dipilih. Berdasarkan hal tersebut maka sampel dalam penelitian ini ditetapkan kelas VIII-3 sebagai kelas eksperimen dan kelas VIII-2 sebagai kelas kontrol.

Data yang dianalisis pada penelitian ini, diperoleh dari tes kemampuan berpikir kritis matematis siswa dan angket metakognisi dari Metacognitive Awareness Inventory (MAI) diadaptasi langsung dari Schraw dan Dennison. Tes yang diberikan terdiri dari pretes dan postes, pretes diberikan pada awal pembelajaran yaitu 
sebelum adanya perlakuan sedangkan postes diberikan diakhir pembelajaran atau setelah perlakuan. Dari skor pretes dan postes kemampuan berpikir kritis matematis dan metakognisi yang telah diubah ke nilai MSI, dihitung $\mathrm{N}$-gain (gain ternormalisasi). Perhitungan $\mathrm{N}$ gain dilakukan dengan tujuan untuk menghilangkan faktor tebakan dan efek nilai tertinggi sehingga terhindar dari kesimpulan yang bias. Rentang nilai Ngain adalah 0 sampai dengan 1 .

Selanjutnya, nilai $\mathrm{N}$-gain inilah yang diolah, dan pengolahannnya disesuaikan dengan permasalahan dan hipotesis yang diajukan. Pengolahan data dalam penelitian ini dilakukan sebagai berikut: (1) menguji persyaratan statistik yang diperlukan sebagai dasar dalam pengujian hipotesis yaitu menguji normalitas dan homogenitas data baik terhadap bagian-bagiannya maupun secara keseluruhan. Uji normalitas dan homogenitas ini menggunakan Shapiro-Wilk dan uji Levene. (2) Uji-t untuk mengetahui adanya perbedaan peningkatan yang signifikan antara kedua kelas secara keseluruhan dan uji korelasi untuk melihat hubungan antara kemampuan berpikir kritis dan metakognisi siswa. Seluruh perhitungan menggunakan bantuan komputer program SPSS 17.

\section{HASIL PENELITIAN DAN PEMBAHASAN}

\section{Kemampuan Berpikir Kritis Matematis}

\section{a) Analisis Kemampuan Berpikir} Kritis Matematis

Hasil skor pretes kemampuan berpikir kritis matemais pada kelas eksperimen dan kelas kontrol, dapat disajikan pada tabel. 1 berikut ini,

Tabel 1. Data Skor Kemampuan Berpikir Kritis Matematis Siswa Kelas Eksperimen dan Kelas Kontrol

\begin{tabular}{|c|l|c|c|c|c|c|c|}
\hline \multirow{2}{*}{ Kemampuan } & \multirow{2}{*}{ Skor } & \multicolumn{3}{|c|}{ Eksperimen } & \multicolumn{3}{c|}{ Kontrol } \\
\cline { 2 - 8 } & & $\mathbf{N}$ & $\overline{\boldsymbol{x}}$ & $\mathbf{S D}$ & $\mathbf{N}$ & $\overline{\boldsymbol{x}}$ & SD \\
\hline \multirow{3}{*}{$\begin{array}{c}\text { Berpikir } \\
\text { kritis }\end{array}$} & Pretes & 30 & 10,7 & 2,38 & 30 & $10 ., 5$ & 2,41 \\
\cline { 2 - 8 } & Postes & 30 & 22,3 & 2,8 & 30 & 18,5 & 2,92 \\
\cline { 2 - 7 } & N-gain & 30 & 0,67 & 0,15 & 30 & 0,46 & 0,12 \\
\hline \multicolumn{6}{|c|}{ Skor Maksimum Ideal = 24 } \\
\hline
\end{tabular}

Hasil analisis terhadap data pretes, diperoleh nilai rata-rata dan simpangan baku pada kelas eksperimen adalah 10,7 dan 2,38 sedangkan nilai rata-rata dan simpangan baku pada kelas kontrol adalah 10,5 dan 2,8 dari skor maksimum 24. Rataan pretes kedua kelas relatif sama, hal ini menunjukkan bahwa kemampuan berpikir kritis siswa pada kedua kelas tersebut sebelum pembelajaran relatif sama.

Berdasarkan hasil uji normalitas data pretest pada kelas eksperimen dan kelas kontrol diperoleh berturut-turut masing-masing nilai sig. $=0,125$ dan $0,133>\alpha=0.05$, sehingga $\mathrm{H}_{0}$ diterima artinya sampel berasal dari populasi berdistribusi normal. Hasil uji normalitas data pretes kemampuan berpikir kritis diperoleh berdistribusi normal, langkah selanjutnya dilakukan uji homogenitas. Pengujian menggunakan uji Homogeneity of Variance diperoleh bahwa skor pretes kemampuan berpikir kritis siswa kelas eksperimen dan kelas kontrol memiliki nilai Sig. 0,298>0,05, sehingga $\mathrm{H}_{0}$ diterima. Hal ini menunjukkan bahwa data skor pretes dari kedua kelas adalah berasal dari varians yang homogen. 
Kemudian dilanjutkan dengan uji kesamaan rataan dua sampel melalui uji-t menggunakan Compare Mean Independent Samples Test. Uji kesamaan rataan data skor pretes digunakan untuk membuktikan bahwa tidak adanya perbedaan kemampuan awal kedua kelas. Kriteria pengujian tolak Ho jika sig < 0,05. Secara ringkas hasil uji kesamaan rataan yang diperoleh yaitu $0,665>\alpha=0.05$, artinya $\mathrm{H}_{0}$ diterima. Hal ini menunjukkan bahwa tidak terdapat perbedaan yang signifikan antara skor pretes kemampuan berpikir kritis matematis siswa kelas eksperimen dan kelas kontrol. Jadi, dapat disimpulkan bahwa kemampuan awal kedua kelas adalah sama.

\section{b) Analisis Peningkatan Kemampuan Berpikir Kritis Matematis}

Analisis peningkatan kemampuan berpikir kritis secara keseluruhan bertujuan untuk membuktikan hipotesis pertama dari penelitian ini. Skor kemampuan berpikir kritis siswa kelas eksperimen menunjukkan kenaikan sekitar 0,21 lebihnya dari kelas kontrol. Walaupun demikian, tetap diperlukan uji statististik lanjut untuk membuktikan bahwa peningkatan kemampuan berpikir kritis siswa kelas eksperimen lebih baik dari kelas kontrol.

Selanjutnya terlebih dahulu dilakukan uji normalitas dan uji homogenitas terhadap gain pada kedua kelompok data tersebut. Uji normalitas dihitung dengan menggunakan bantuan program SPSS 17.0 pada uji statistik Shapiro-Wilk diperoleh nilai signifikansi berturut-turut untuk kelas eksperimen dan kontrol nilai yaitu 0,657 dan $0,410>\alpha=0,05$ sehingga $\mathrm{H}_{0}$ diterima. Artinya kedua kelompok data skor gain kemampuan berpikir kritis matematis ini berdistribusi normal.

Dikarenakan hasil skor gain ternormalisasi berdistribusi normal, maka dilanjutkan dengan melakukan pengujian homogenitas varians terhadap kelas kontrol dan kelas eksperimen pada kemampuan berpikir kritis matematis. Untuk uji homogenitas varians kedua kelompok data gain kelas eksperimen dan kelas kontrol diperoleh nilai Signifikansi sebesar $0.120>0.05$. Artinya, kedua kelompok data gain kelas eksperimen dan kontrol memiliki varians yang homogen.

Selanjutnya karena kelompok data gain kelas eksperimen dan kelas kontrol keduanya mempunyai data yang berdistribusi normal dan varians yang homogen maka untuk mengetahui signifikansi perbedaan rataan kedua kelompok data dilakukan analisis data secara keseluruhan melalui uji-t. Analisis ini dilakukan untuk melihat pengaruh langsung dari dua perlakuan berbeda yang diberikan terhadap kemampuan berpikir kritis matematis siswa.

Secara ringkas hasil uji perbedaan rata-rata $\mathrm{N}$-gain kemampuan berpikir kritis matematis ditunjukkan pada tabel berikut.

Tabel 2. Uji Perbedaan Rata-rata Gain-Ternomalisasi Kemampuan Berpikir Kritis Matematis

\begin{tabular}{|c|c|c|}
\hline \multicolumn{3}{|c|}{ t-test for Equality of Means } \\
\hline$T$ & $D f$ & Sig. (2-tailed) \\
\hline 12.362 & 58 & 0.000 \\
\hline
\end{tabular}

Aksioma 
Pada Tabel 2 terlihat perolehan nilai Sig. (2-tailed) yaitu 0,000 . Kemudian dari nilai sig.(2-tailed) adalah 0,000 diperoleh nilai sig (1tailed $)=\frac{\text { sig }(2-\text { tailed })}{2}=\frac{0,000}{2}=0,000$. Karena nilai sig. $(1$-tailed $)=0,000<\alpha=$ 0,05 maka $\mathrm{H}_{0}$ ditolak, sehingga $\mathrm{H}_{1}$ diterima. Dengan demikian hipotesis pertama yang telah dirumuskan dalam penelitian ini yaitu "peningkatan kemampuan berpikir kritis matematis siswa melalui pendekatan problem solving lebih baik daripada siswa dengan pendekatan konvensinal" diterima.

Adanya peningkatan kemampuan berpikir kritis menunjukkan bahwa aktivitas/tahap-tahap pendekaan pada pendekatan problem solving sesuai digunakan dalam pembelajaran yang bersifat menyelesaikan masalah, karena siswa akan terlatih/terbiasa menyelesaikan masalah baik yang bersifat rutin maupun non-rutin dengan memahami masalah tersebut, merancang rencana penyelesaian, melaksanakan rancana dan erakhir dapat menarik kesimpulan pada masalah yang diselesaikan tersebut dari situasi/informasi yang ada. Aktivitas tersebut dapat membantu meningkatkan ingatan, pemahaman serta kemampuan berpikir kritis setelah pembelajaran, sadar apa yang dilakukan, bagaimana melakukan dan bagaimana mencari penyelesaiannya. Hasil penelitian ini juga bersesuaian dengan beberapa penelitian yang menemukan bahwa pembelajaran melalui pendekatan problem solving dapat meningkatkan kemampuan berpikir kritis matematis siswa (Ismaimuza ,2010; Fariha, 2012; Susanti, 2013; Jumaisyaroh, 2014).

\section{Metakognisi Siswa}

a) Analisis Metakognisi Siswa
Sebelum Perlakuan
Data pretes metakognisi siswa diperoleh dari perhitungan hasil angket MAI yang telah diubah menjadi data interval melalui Method of Successive Interval (MSI). Data metakognisi diperoleh melalui angket yang diberikan sebelum perlakuan dan setelah perlakuan pada kelas eksperimen dan kelas kontrol. Berikut adalah analisis deskripsi skor metakognisi siswa pada kedua kelas.

Tabel 3. Deskripsi Data Metakognisi siswa

\begin{tabular}{|c|c|c|c|c|c|c|}
\hline \multirow{2}{*}{ Kelas } & \multirow{N}{*}{ Angket } & $\begin{array}{c}\text { Skor } \\
\text { Max }\end{array}$ & $\begin{array}{c}\text { Skor } \\
\text { Min }\end{array}$ & $\bar{x}$ & SD \\
\hline \multirow{2}{*}{ Eksperimen } & \multirow{2}{*}{30} & Sebelum & 51 & 43 & 46,77 & 1,27 \\
\cline { 3 - 7 } & & Setelah & 103 & 86 & 95,00 & 1,81 \\
\hline \multirow{2}{*}{ Kontrol } & \multirow{2}{*}{30} & Sebelum & 52 & 44 & 47,13 & 1,28 \\
\cline { 3 - 7 } & & Setelah & 77 & 59 & 67,63 & 1,53 \\
\hline
\end{tabular}

Pada Tabel 3. diperoleh rataan metakognisi siswa sebelum perlakuan kelas eksperimen dan kontrol berturutturut 46,77 dan 47,13 dari skor maksimum ideal 120. Hal ini menunjukkan bahwa metakognisi siswa pada kedua kelas tersebut sebelum pembelajaran relatif sama. Pada penyebaran metakognisi siswa antara kelas eksperimen dan kelas kontrol relatif sama, dikarenakan simpangan baku kedua kelas tidak jauh berbeda yaitu 1,27 dan 1,28.

Adapun rataan skor metakognisi setelah perlakuan diperoleh kelas eksperimen dan kelas kontrol berturut yaitu 95,00 dan 67,63, diperoleh rataan kelas eksperimen lebih tinggi 
dibandingkan rataan kelas kontrol untuk metakognisi siswa. Hal ini menunjukkan bahwa terjadi peningkatan skor metakognisi siswa setelah dilakukan pembelajaran melalui pendekatan problem solving. Dari uji normalitas dan homogenitas pretes metakognisi diperoleh bahwa nilai Sig. untuk kelas eksperimen dan kontrol berturut-turut yaitu 0,419 dan 0,057 > 0.05 sehingga $\mathrm{H}_{0}$ diterima, maka kedua data metakognisi siswa dari kedua kelas tersebut berdistribusi normal. Pada uji homogenitas varians data diperoleh nilai signifikansi sebesar $0,707>0.05$. Hal ini menunjukkan bahwa data skor metakognisi sebelum perlakuan dari kedua kelas adalah berasal dari varians yang homogen. Dengan demikian, karena diperoleh data skor metakognisi sebelum perlakuan berdistribusi normal dan memili varians yang homogen maka selanjutnya dilakukan analisis untuk mengetahui seberapa besar peningkatan metakognisi siswa setelah menerima pembelajaran melalui pendekatan problem solving.

\section{b) Analisis Peningkatan Metakognisi Siswa}

Analisis peningkatan metakognisi siswa secara keseluruhan bertujuan untuk membuktikan hipotesis kedua dari penelitian ini. Uji analisis yang dilakukan yaitu uji normalitas dan homogenitas untuk N-gain dari kedua kelompok kelas eksperimen dan kelas kontrol. Untuk uji normalitas diperoleh berturut-turut kelas eksperimen dan kontrol nilai signifikansinya sebesar 0,505 dan 0,810 lebih besar dari nilai 0,05, sehingga $\mathrm{H}_{0}$ diterima. Artinya kedua kelompok data skor gain metakognisi ini berdistribusi normal. Selajutnya dilakukan uji homogenitas dan diperoleh nilai signifikansinya sebesar $0,154>0.05, \mathrm{H}_{0}$ diterima yang menyatakan bahwa kedua kelompok data memiliki varians yang sama. Artinya, kedua kelompok data gain kelas eksperimen dan kontrol memiliki varians yang homogen. Sehingga dapat disimpulkan data gain metakognisi siswa kelas eksperimen dan kelas kontrol berdistribusi normal serta berasal dari varians yang homogen.

Selanjutnya dilakukan pengujian hipotesis penelitian. Adapun hipotesis yang diuji adalah "Peningkatan metakognisi siswa yang memperoleh pembelajaran dengan pendekatan Problem Solving lebih baik daripada metakognisi siswa yang memperoleh pembelajaran konvensional". Analisis data metakognisi siswa secara keseluruhan akan dianalisis menggunakan uji-t. Secara ringkas hasil uji perbedaan rata-rata skor gain metakognisi siswa ditunjukkan pada Tabel berikut.

Tabel 4. Hasil Uji Perbedaan Rata-rata Skor N-Gain Metakognisi Siswa

\begin{tabular}{|c|c|c|c|c|}
\hline \multicolumn{2}{|c|}{$t$-test for Equality of Means } & \multirow{2}{*}{ Keterangan } & \multirow{2}{*}{ Kesimpulan } \\
\hline$T$ & $D f$ & Sig. (2-tailed) & & \\
\hline 11,729 & 58 & 0.000 & $\mu_{1}>\mu_{2}$ & $\mathrm{H}_{0}$ ditolak \\
\hline
\end{tabular}

Setelah dilakukan perhitungan, diperoleh nilai Sig. (2-tailed) yaitu 0,000. Kemudian dari nilai sig.(2-tailed) $=0,000$ diperoleh nilai sig $(1$-tailed $)=$ $\frac{\operatorname{sig}(2-\text { tailed })}{2}=\frac{0,000}{2}=0,000$. Oleh

Aksioma demikian, karena nilai sig.(1-tailed $)=$ $0,000<0,05$ maka $\mathrm{H}_{0}$ ditolak dan $\mathrm{H}_{1}$ diterima, Dengan demikian dapat disimpulkan hipotesis kedua yang menyatakan "peningkatan metakognisi 
siswa yang diajarkan melalui pendekatan problem solving lebih baik daripada metakognisi siswa yang diajarkan melalui pembelajaran konvensional" diterima. Hal ini menunjukkan bahwa melibatkan siswa secara aktif dalam kegiatan pembelajaran serta menyadari akan kemampuannya sendiri dapat meningkatkan metakognisi siswa. Hal ini sesuai dengan beberapa penelitian yang menyimpulkan bahwa pendekatan problem solving dapat meningkatkan metakognisi siswa (Garrett \&
Mazzocco, 2006; Hollingworth \& McLoughlin, 2002; Tan, 2004).

\section{Analisis Korelasi Kemampuan Berpikir Kritis dengan Metakognisi Siswa}

Perhitungan Analisi korelasi korelasi dilakukan dengan bantuan SPSS 17.0. Besar kecilnya keeratan hubungan antarvariabel dinyatakan dengan koefisien korelasi (r), yang diklasifikasikan menurut kriteria berikut.

Tabel 5. Interpretasi Nilai Korelasi

\begin{tabular}{|c|l|}
\hline Besar $\mathbf{r}$ & \multicolumn{1}{|c|}{ Interpretasi } \\
\hline $0,00<\mathrm{r}<0,20$ & Hubungan sangat lemah (diabaikan, dianggap tidak ada) \\
\hline $0,20 \leq \mathrm{r}<0,40$ & Hubungan rendah \\
\hline $0,40 \leq \mathrm{r}<0,70$ & Hubungan sedang/cukup \\
\hline $0,70 \leq \mathrm{r}<0,90$ & Hubungan kuat/tinggi \\
\hline $0,90 \leq \mathrm{r} \leq 1,00$ & Hubungan sangat kuat/tinggi \\
\hline
\end{tabular}

Hasil analisis korelasi disajikan pada tabel berikut:

Tabel 6. Hasil Uji Korelasi antara Metakognisi Siswa dengan Kemampuan Berpikir Kritisnya

\begin{tabular}{|c|c|c|c|}
\hline & & B.Kritis & Metakognisi \\
\hline \multirow[t]{3}{*}{ B.Kritis } & Pearson Correlation & 1 & $.625^{* * *}$ \\
\hline & Sig. (2-tailed) & & .000 \\
\hline & $\mathrm{N}$ & 30 & 30 \\
\hline \multirow[t]{3}{*}{ Metakognisi } & Pearson Correlation & $.625^{* *}$ & 1 \\
\hline & Sig. (2-tailed & .000 & \\
\hline & $\mathrm{N}$ & 30 & 30 \\
\hline
\end{tabular}

Pada tabel 6. terlihat bahwa nilai $r$ hubungan antara metakognisi siswa dengan kemampuan berpikir kritis adalah sebesar 0,625. Nilai ini tergolong besar untuk suatu hubungan antar variabel. Sehingga dapat disimpulkan bahwa terdapat hubungan antara metakognisi siswa dengan kemampuan berpikir kritis matematis. Uji signifikansi pada pada tabel menunjukkan nilai sebesar Sig. (2-tailed $=0,000 \leq \propto=0,05$, artinya hubungan antara metakognisi siswa dengan kemampuan berpikir kritisnya adalah signifikan. Nilai korelasi yang diperoleh adalah 0,625 (positif), artinya korelasi menunjukkan searah sehingga apabila semakin tinggi metakognisi siswa maka semakin tinggi pula kemampuan berpikir kritisnya. Siswa yang memiliki metakognisi yang baik mampu untuk mengamati pemikiran atau penelitiannya sendiri. Sehingga dengan mengembangkan metakognisinya, 
secara tidak sadar siswa juga mengembangkan pemahamannya dalam proses berpikir kritis maupun logis.

Livingston (2003) menyatakan bahwa kemampuan seseorrang menggunakan pengetahuannya untuk merencanakan langkah-langkah yang akan digunakan dalam menyelesaikan tugas belajarnya, mengambil langkahlangkah yang diperlukan untuk memecahkan masalah serta merefleksi dan mengevaluasi hasil belajar merupakan bagian dari ketrampilan metakognisi sedangkan kemampuan memecahkan masalah merupakan bagian dari ketrampilan berpikir kritis. Hal ini sejalan dengan beberapa penelitian yang mengungkapkan keterkaitan kemampuan berpikir kritis dengan metakognisi di bidang ilmu lain (Malahayati, dkk, 2015; Diella, 2014; Sadeghi\& Hassani\& Rahmatkhah, 2014; Yildirim \& Zehra, 2013; Sumampouw, 2011).

\section{KESIMPULAN DAN SARAN}

Berdasarkan hasil penelitian ini disimpulkan bahwa (1) Peningkatan kemampuan berpikir kritis matematis siswa yang diajarkan melalui pendekatan problem solving lebih baik daripada siswa yang diajarkan melalui pembelajaran konvensional, (2) Peningkatan metakognisi siswa yang diajarkan melalui pendekatan problem solving lebih baik daripada siswa yang diajarkan melalui pembelajaran konvensional, (3) Terdapat hubungan positif dan signifikan antara metakognisi siswa dengan kemampuan berpikir kritis matematis.

Adapun beberapa saran dalam penelitian ini adalah (1) Penelitian ini hanya terbatas pada materi persamaan linear dua variabel, diharapkan pada peneliti lainnya untuk mengembangkan pembelajaran dengan pendekatan problem solving pada kemampuan matematis lainnya dan materi-materi lain yang sesuai, (2) Pada pelaksanaan pembelajaran dengan pendekatan problem solving kemungkinan terdapat kendala-kendala pada awal pembelajaran sehingga perlu adanya antisipasi dari guru dan siswa perlu dilatih menjawab masalah-masalah matematika, (3) penelitian tentang metakognisi siswa belum maksimal dilakukan oleh peneliti dan memiliki waktu yang terbatas yaitu hanya lima kali pertemuan. Oleh karena itu sangat perlu dilakukan penelitian tentang metakognisi siswa dalam kurun waktu yang lebih lama untuk melihat proses dan faktor-faktor yang dapat meningkatkan metakognisi siswa.

\section{DAFTAR PUSTAKA}

Diella, D. (2014). Hubungan kemampuan Metakognisi dengan Kemampuan Berpikir Kritis dan Sikap Ilmiah Siswa. Tesis. Tidak Diterbitkan. Universitas Pendidikan Matematika

Djamara, S. B \& Zain, A. (2006). Strategi Belajar Mengajar. Jakarta: Rineka Cipta.

Fariha, M. (2012). Kemampuan Berpikir Kritis Matematis dan Kecemasan Matematika dalam Pembelajaran dengan Pendekatan Problem Solving. Jurnal Peluang, 1(2), 43-50.

Fisher, A. (2001). Critical Thinking: An Introduction. New York: Cambridge University Press.

Friedrichsen, P.M. (2001). A Biology Course for Prospective Elementary Teachers. Journal of American Biology Teacher, 63(8), 562-568. 
Garret, A.J \& Mazzocco, M.M.M. (2006). Development of The Metacognitive Skills of Prediction and Evaluation in Children With or Without Math Dissability. Journal of Learning Disabilities Research \& Practice, 21(2), 77-87.

Gulo, W. (2002). Strategi Belajar Mengajar. Jakarta: PT. Grasindo

Hamzah. (2003). Meningkatkan Kemampuan Pemecahan Masalah Matematika Siswa Sekolah Lanjutan Tingkat Pertama Negeri di Bandung melalui Pendekatan Problem Posing. Disertasi. Tidak Diterbitkan. Universitas Pendidikan Indonesia.

Hollingworth, R. \& McLoughlin. (2002). The Development Science Student's Metacognitive Problem Solving Skils. Journal of Educational Technology, 17(1), $50-63$.

Hudoyo, H. (2003). Pengembangan Kurikulum dan Pembelajaran Matematika. Malang: Universitas Negeri Malang.

Ismaimuza, D. (2010). Kemampuan berpikir Kritis dan Kreatif Matematis Siswa SMP Melalui Pembelajaran Berbasis Masalah dengan Strategi Konflik Kognitif. Disertasi. Tidak Dipublikasi. UPI

Iway, Y. (2011). The Effect of Metacognitive Reading Strategies: Pedagogical Implication for EFL/ESL Teachers. Journal of The Reading Matrix, 11(2), 150-159.

Jumaisyaroh.T, Napituputulu, E.E, Hasratuddin. (2014).
Peningkatan Kemampuan Berpikir Kritis Matematis dan Kemandirian Belajar Siswa SMP melalui Pembelajaran Berbasis Masalah. Jurnal Kreano,5(2). 157-169.

Khodijah, N.(2006). Psikologi Belajar. Palembang: IAIN Raden Fatah Press.

Livingston, J. A (2003). Metacognition: An Overview State Univ. Diakses pada 08 Desember 2016 dari http://eric.ed.gov

Malahayati, E.N, Corebima, A.D \& Zubaidah, S. (2015). Hubungan Ketrampilan Metakognitif dan Kemampuan Berpikir Kritis dengan Hasil Belajar Biologi siswa SMA dalam Pembelajaran PBL. Jurnal Pendidikan Sains, 3(4), 178-185.

Nugraha, A. (2011). Pengembangan Perangkat Pembelajaran Matematika dengan Pendekatan Metakognitif Berbasis Humanistik untuk Menumbuhkan Berpikir Kritis Siswa pada Materi Himpunan Kelas VII. Jurnal PP, 1(1). 1-9.

Panaoura, A. \& Philippou, G. (2006). The Measurement of Young Pupils' Metacognitive Ability in Mathematic: The Case of SelfRepresentation and SelfEvaluation. Diakses pada 14 Agustus 2016 dari http://ucy.accy;Internet

Peng, C.N. (2004). Successful ProblemBased Learning for Primary and Secondary Classrooms (PDF.eBook). Singapore: Federal Publications. 
Prihandoko, A. C. (2006). Memahami Konsep Matematika Secara Benar dan Menyajikannya dengan Menarik. Jakarta: Depdiknas.

Ruseffendi. E. T. (2005). Dasar-Dasar Penelitian Pendidikan \& Bidang Non-Eksakta. Bandung: Tarsito.

Sadeghi, B, Hassani, M. T, dan Rahmatkhah, M. (2014). The Relationship between EFL Learners' Metacognitive Strategies, and Their Critical Thinking. Journal of Language Teaching and Research, 5(5), 1167-1175.

Setiawan. (2008). Prinsip-prinsip Penilaian Pembelajaran Matematika SMA. Yogyakarta: Pusat Pengembangan dan Pemberdayaan Pendidik dan Tenaga Kerja Kependidikan Matematika.

Suharman. (2005). Psikologi Kognitif. Surabaya: Srikandi.

Sumampouw, H.M. (2011). Ketrampilan Metakognitif dan Berpikir Tingkat Tinggi dalam
Pembelajaran Genetika. Jurnal Bioedukasi, 4(2), 23-39.

Suryabrata, S. (2004). Psikologi Pendidikan. Bandung: PT. Remaja Rosdakarya.

Susanti, D. R. (2013). Pengaruh Penggunaan Metode Problem Solving terhadap Kemampuan Berpikir Kritis Matematika Siswa. Teris. Tidak Dipublikasi. Universitas Negeri Gorontalo.

Tan, O. S. (2004). Enhanching Thinking Problem Based Learning Approached. Singapura: Thomson Co.

Wale, J. A. (2006). Matematika Sekolah Dasar dan Menengah. Terjemahan Suyono dari Elementary and Middle School Mathematics. Jakarta: Erlangga.

Yildirim, S \& Zehra N. E. (2013). The Relationship between University Students' Metacognitive Awereness and Solving Similar Type of Mathematical Problem. Eurasia Journal of Mathematics, Science \& Technology Education, 9(4), 411-415. 